\title{
Who Gets to Withdraw the Status?
}

\begin{abstract}
This chapter determines the extension of Union citizenship by asking: Who gets to withdraw the status of Union citizenship? It is a complex and debated issue. The various options are presented and the anticipated consequences for both the UK and EU states are fleshed out. Venues for challenging the loss of status are also discussed. The chapter discusses limits to what the UK can do to protect itself against abuse of multiple citizenship and what member states are allowed to do to UK citizens resident in their territories. The key finding is that while member states are in principle free to revoke the status of Union citizen, former member states are not unbounded in stripping Union citizens of their acquired territorial rights.
\end{abstract}

Keywords European citizenship - Brexit - Freedom of movement - Right of residence $\cdot$ EU law $\cdot$ Migration law $\cdot$ International law $\cdot$ Political rights Citizens' initiative

\subsection{Who Gets to Withdraw Union Citizenship?}

This chapter explores the extension of Union citizenship, by asking who determines loss of Union citizenship. Can member states impose involuntary loss of EU citizenship? What are the limits to state discretion in this area? What material consequences may follow from such limits?

P. Mindus, European Citizenship after Brexit, Palgrave Studies in European Union Politics, DOI 10.1007/978-3-319-51774-2_6 
It was long supposed that the only way to lose European citizenship for a European citizen was by losing member state nationality. Already the Resolution on the draft Treaty establishing the EU from 14 February 1984, stressed that European citizenship 'may not be $(\ldots)$ forfeited (...) independently of nationality of a member state. ${ }^{1}$ With Brexit the nationality of the former member state is not lost, but Union citizenship would be. So Brexit proves that there is another way to lose 'the fundamental status': Ex lege automatic loss due to the exiting of a member state. Indirectly, Article 50 adds a ground for loss of Union citizenship. This ground for loss finds its mirror image in the acquisition of Union citizenship ex lege for states acceding to the Union according to Article 49 TFEU. The argument, in keeping with traditional theories of statehood, is that any mutation to the legal status of territory can thus naturally be expected to generate effects for the citizenship status of (at least some) inhabitants.

With Brexit, we are witnessing a form of involuntary loss $^{2}$ of citizenship en masse, ex lege, imposed on EU citizens of British nationality that, however, does not create statelessness and is likely to be tolerated under public international law. Involuntary here indicates the modality of loss, not the will of the status holder. Legally, the loss of citizenship is involuntary insofar as it is not a case of (individual) renunciation. In the case of Brexit one may also make the political claim that it is involuntary because $48 \%$ expressed their will to remain European citizens; certain territories voted massively in favour of staying and the UK citizens residing abroad were disenfranchised, even though they were among the most affected. ${ }^{3}$ Can such an involuntary loss be unilaterally imposed by an exiting state? If so, what consequences follow in the current legal setting? No Treaty provision explicitly deals with the consequences of loss of Union citizenship. Any consequences would need to be found in non-primary sources.

At first sight, whether involuntary loss can be imposed by the state that exits seems very simple to answer. Even though access to the status is, formally, regulated by the Treatises, Union citizenship is not an autonomous status. The choice of using mere lexical reference to member state nationality laws in Article 20 TFEU leaves the Herren der Verträge (Masters of the Treatises), in principle, free to determine such criteria. This has, among other things, permitted member states aiming to deprive of rights certain minority groups among their citizens to engage in the inelegant practice of bringing unilateral declarations on the meaning of nationality for the purposes of EU law. ${ }^{4}$ 
All in all, Article 20 TFEU leaves little doubt about who owns the competence: 'Every person holding the nationality of a member state shall be a citizen of the Union. Citizenship of the Union shall be additional to and not replace national citizenship.' It is confirmed by the wording of the declaration annexed to the Maastricht Treaty on the nationality of member states: 'The question whether an individual possesses the nationality of the Member state shall be settled solely by reference to the national law of the Member State concerned. ${ }^{5}$ In this context, it is worth recalling the doubts of the Danes, expressed during the summit in Edinburgh, who feared that European citizenship would substitute their own infødsret. Only after many specifications as to the adjunctive character of the new status, did Denmark ratify the Treaty of Maastricht following a second referendum (Howarth 1994).

The rule governing the allocation of competence in the area of nationality law is entrenched in international law and recently codified in the Article 3(1) European Convention on Nationality: 'Each State shall determine under its own law who are its nationals.' Member states share this view too. Suffice to say that the German constitutional court, in its Lissabon Urteil from 2009, expressed the point as follows: 'In view of the elaboration of the rights of the citizens of the Union, the German state people (Staatsvolk) retains its existence as long as the citizenship of the Union does not replace the citizenships of the Member States or is superimposed on it. ${ }^{6}$

Member states own the competence to define criteria for acquisition and loss of their own nationality. Nationality of a member state is a necessary criterion for acquisition of EU citizenship. This determines the derivative nature of EU citizenship that confers upon it the quality of a complementary status, different from dual citizenship status common in federal states. ${ }^{7}$ Unclearness hovers above the construct and it allows indirect influence of member states on the definition of who counts a Union citizens. For some, EU law and domestic law would even constitute competing norms (e.g. Evans 1991). As mentioned in Chapter 2, a famous paradox is that as a result of the Spanish option right for the children of former Spanish nationals born in Spain (Art. 20 of the Spanish Civil Code), Fidel Castro himself could immediately opt for European citizenship without moving from Havana (De Groot 2004, p. 7).

One might be tempted to conclude that the remedial solutions for avoiding the loss of status for the category of British nationals living in other member states are therefore nil: Vain would be the attempt to domesticate the sovereign power to exclude of an exiting member state. 
The short answer to the question put in the title of this section is member states, but a more nuanced answer adds granu salis. The question whether an individual possesses the nationality of the member state is no longer settled solely by reference to the national law. The famous declaration attached to the Maastricht Treaty on 'nationality' was removed from the annex of the TEU after entry into force of the Lisbon Treaty. There are limits to the ability of member states to impose involuntary loss of citizenship entailing curtailment of previously enjoyed rights. Supranational scrutiny of state discretion in this area is increasing.

\subsection{Limits of Public International Law}

A set of international norms pertains to the withdrawing of status civitatis as such. The power of states to determine its members is not unfettered. The decision to revoke nationality finds its limits in international norms in the form of treaties or customary law. ${ }^{8}$ Leading principles on loss of nationality can be found in the Articles 5-9 of the 1961 Convention on the Reduction of Statelessness and as well as the 1997 European Convention on Nationality. However, such instruments would not apply since Brexit would not cause statelessness. So what other sources are there?

Article 15 of the Universal Declaration on Human Rights states that 'everyone has the right to a nationality,' which may not be withdrawn arbitrarily. Although the Universal Declaration is not a binding instrument, the forbiddance of arbitrary deprivation is repeated in other treatises and instruments. 'Deprivation,' which domestically is an act of the administration, in this setting covers ex lege loss of nationality. 'An example of such an arbitrary loss is, for example, a retroactive restriction of a ground for acquisition. ${ }^{10}$

A first practical implication follows from here. The UK cannot, lest it violates international law, retroactively deprive second country nationals who have naturalised in the UK of their current status were it somehow to push for expulsion of 'non-Brits' altogether; nor can the UK retroactively deprive of British nationality citizens who, having the citizenship by birth of another EU member state, also naturalised in the UK. This is a first limit to the possibilities of the exiting state to protect itself against instrumental use of multiple citizenship.

Now all provisions on loss of citizenship need to be read in the light of the general principle of the UNDHR banning arbitrary deprivation. The Universal Declaration does not specify the exact circumstances under 
which one would have to conclude that there is an arbitrary withdrawal (Marescaux 1984) but some general principles follow from this obligation to avoid arbitrariness. ${ }^{11}$ These principles have to be observed not only if the loss or deprivation would cause statelessness, but in all cases where a person would be stripped of a citizenship. The Brexit loss provision would need to obey these principles.

An intriguing issue is whether the loss of Union citizenship entailed by Brexit might demonstrate arbitrary features in its being unchallengeable. The application of loss provisions must be possible to challenge in court, but in this scenario, it is unclear whether the principle would imply letting British citizens challenge the loss provision before an English court, before courts in member states where they are residing, or before the European Court of Justice. As we shall see there is a quite limited possibility that the European Court of Justice might be involved. Were this the case, the Brexit loss provision would comply with international law requirement on being challengeable. While it seems likely that some rights associated with Union citizenship could be upheld if deprivation of these was challenged, it is less clear if loss of the status as such could be challenged, let alone if it could be frozen for the British citizens concerned.

\subsection{EU Law Limits to State Discretion}

At first the Brexit case of loss of Union citizenship does not seem to fall within the remit of European law precisely because it would occur simultaneously to the UK's withdrawal, but appearances deceive. The jurisprudence of the European Court of Justice has imposed certain limitations on the autonomous powers of the member States to determine issues relating to the acquisition and loss of nationality. Generally speaking, member states need to pay 'due regard to Community law.' This has been the obiter dictum since the European Court of Justice started to express itself on the matter in the early Nineties, with the case of the Argentinian dentist Micheletti. ${ }^{12}$

On that occasion, the European Court of Justice concluded that:

under international law, it is for each Member State, having due regard to Community law, to lay down the conditions for the acquisition and loss of nationality. However, it is not permissible for the legislation of a Member State to restrict the effects of the grant of the nationality of another Member State by imposing an additional condition for recognition of 
that nationality with a view to the exercise of the fundamental freedoms provided for in the Treaty. ${ }^{13}$

Besides public international law, member states are to respect general principles of European law that applies to matters of loss of Union citizenship, including the principle of proportionality - that has attracted much interest in the wake of Rottman - but also the principle of equal treatment, the principle of protection of legitimate expectations and the principle of sincere cooperation (Gemeinschaftstraue).

In Rottman, the European Court of Justice acknowledged that member states may legitimise the revocation of nationality and its consequences for the status of European citizens for the protection of their special relationship with their nationals, based on 'solidarity and good faith, and the reciprocity of rights and duties, which forms the bedrock of the bond of nationality. ${ }^{14}$ Such legitimate interest is, however, subject to the test of proportionality and other limits. The European Court of Justice left it up to the national court to decide whether it would be proportional to withdraw German nationality. Even after Rottman it is compatible with European law to deprive naturalised of citizenship in case of fraud which is also consistent with international law - but member states:

must not solely adhere to this principle of proper administration in accordance with their own internal (administrative law), where exclusively national points of view will be dealt with (...); but then a second proportionality test must be applied regarding this loss of the fundamental status of Union citizen. That element can, of course, already be included in the proportionality test by national law, but to the extent that it is not the case, it must be examined separately. (Jessurun d'Oliveira 2011, p. 8)

For completing the proportionality test the European Court of Justice provides a number of criteria to take into consideration: The position of family members who might lose rights of residence; the seriousness of the fraud involved; time elapsed between naturalisation and deprivation; if the person may recover prior nationality. It has been stressed that the principle of proportionality ought to be paramount to all decisions on loss, including those where loss occurs automatically (ex lege). Since Rottman, it is clear that member states are subjected to the general principles of European law in matters such as loss of Union citizenship. 
Nationality law belongs to the domaine réservé but domestic choices are not neutral vis-à-vis Union citizenship. There may be incentives for the UK to adopt or modify domestic provisions in a way, however, that would need to pay 'due regard' to European law. ${ }^{15}$

\subsubsection{Resisting Temptation}

An exiting member state has a strong interest to curb opportunities to fool its intention to exit. A palatable way of doing so is to retain nationality of the exiting state and EU citizenship: By having, or acquiring, multiple citizenship, by birth or by naturalisation, in the exiting state and in other member states that do not enforce a ban on multiple nationalities. Multiple nationalities may be the answer for many wishing to retain both residence rights in the UK and free movement in the Union. This is especially the case in Northern Ireland, which already has half a million Irish passport holders. Many people in the UK are Irish citizens by descent from parents or grandparents born in Northern Ireland or the Republic of Ireland. In some cases, in order to establish their citizenship, they will first need to enter their names on the register of foreign births. But for many people asserting their Irish citizenship, which has been dormant is simply a matter of applying for an Irish passport (Dzankic 2016).

After Brexit, UK residents with Irish and British citizenship will still be both UK and EU citizens. 'In a future where the UK is proposing to close its borders to EU nationals, this issue [of double citizenship of many Irish] may become very controversial, as EU nationals are unlikely to benefit from similar 'dual nationalities' in large numbers (...) following a full Brexit' (De Mars et al. 2016). Unsurprisingly, the House of Lords European Union Committee launched an inquiry into UK-Irish relations on 1st of September 2016. Under the banner of taking back control, the UK may be spurred to restrict pervasive (ab)use of multiple citizenships and/or to tolerate it only in some cases.

While any exiting State may have a strong incentive to penalise instrumental naturalisation and abuse of multiple citizenships, the case of the $\mathrm{UK}$ is particularly interesting since it has a tradition of tolerance in this regard. Following the 1948 British Nationality Act, multiple nationalities have been tolerated in the UK system: Since 1 January 1949 the voluntary acquisition of a foreign nationality did not automatically cause the loss of British nationality. It was in principle possible for an individual to retain British nationality, combined with citizenship of the Commonwealth 
and/or foreign nationality. British decolonisation allowed for multiple citizenships more often than not, with the exception of not promoting it systematically for territories claiming independence. If the country stays on its path, it will allow multiple citizenship, permitting some people to effectively be British and European citizens at the same time.

Generally, in former British territories that achieved independence, the provisions dealing with the consequences for nationality had a recurring theme: The person who became a national of the newly independent State under its initial laws, would cease on that day to be a British citizen, with exceptions based on a connection with the UK or remaining British colonies (Fransman 2011, p. 607). Similar provisions can be found in the independence acts of the following British colonies: Uganda, Kenya, Gambia, Botswana, Lesotho, Malta, Trinidad \& Tobago, Barbados, Guyana, Jamaica and Cyprus. If we look at nationality provisions in the Independence acts of countries such as the commonwealth country Nigeria, Ghana, the Malayan federation, Zambia or Malawi we recognise the same pattern: The question of who kept British nationality largely depended on whether one would acquire nationality of the newly independent state.

In keeping with this tradition, the UK ought not to oppose retaining of European citizenship on the part of the population that has 'obvious ties' to the EU. ${ }^{16}$ Were British citizens having 'obvious ties' to the EU somehow offered to maintain their prior status as EU citizens, the UK would need to break with its traditional tolerance in order to oppose it. The UK is not well-equipped to prevent instrumental use of multiple citizenships, but it still has some options that it might be tempted to use.

Given the focus on migration in the debate leading up to the referendum, an incentive for the UK could also be to harden its domestic immigration law, or seek to pick and choose which second country nationals it is willing to admit to residency or to naturalisation. This can be done by reforming nationality or immigration law, but there are more subtle ways of achieving this: For example, by sharpening requirements in citizenship tests ${ }^{17}$ to make naturalisation a harder option for low skilled EU migrants, or by raising fees for requiring indefinite leave to remain or for naturalising in the UK. Currently fees are very high and rising and it is unclear what costs for applicants we would be dealing with.

Conversely, the exiting member state may also choose to penalise instrumental naturalisation by its own nationals living in other member states. One option might be to re-introduce additional criteria, such as the 
requirement of 'a genuine link' ${ }^{18}$ to strengthen one's claim of having British citizenship; an option fully in line with international law. This option may lead to stripping of some rights but not of status civitatis as such since the UK does not impose lapse of citizenship because of residence abroad. However, it cannot be excluded that a revirement towards the genuine link doctrine of an exiting member state may implicate statelessness in cases in which the member state provides for loss of citizenship for those citizens who permanently reside in another state and who do not have another nationality to rely on. In ten member states citizens may lose nationality due to continuous residence abroad. ${ }^{19}$ Another option for penalising instrumental naturalisation of British citizens abroad would be making life difficult for UK nationals wishing to renounce to their original citizenship in order to naturalise in states of the Union that enforce a ban on dual nationality, ${ }^{20}$ for example, by raising fees and making it economically costly to renounce.

These incentives, and many others, would need to be resisted. During the two-year interregnum following an invocation of Article 50, the exiting member state would need to observe the limits imposed by European law on its ability to modify its own provisions on nationality and migration. Were the UK to modify its policy in ways incompatible with European law, it could be subjected to infringement procedure by the Commission and judicial review by the European Court of Justice. The policy adopted under the interregnum would also have practical implications once the UK has effectuated the exit from the Union.

\subsubsection{Consequences for the UK}

By paying attention to the doctrinal limits of European law to state discretion in this policy area, the anticipated consequences for the UK are that, during the interregnum phase, European law would still hold and it could possibly have an après-coup effect on the formulation of domestic nationality law. Modifications to policies even within the domaine réservé may come to be scrutinised by the European Court of Justice.

In particular, if the UK passes reforms to its domestic nationality law, these would be subjected to judicial review by the European Court of Justice. The UK would be prevented from hardening its domestic nationality law with the aim to punish instrumental acquisition of multiple nationalities. More precisely, the UK cannot pass domestic nationality provisions easing naturalisation only for some EU citizens: It would 
violate the principle of equality or non-discrimination. The UK would also be prevented from passing domestic nationality provisions having the effect of barring, or rendering more difficult or overly onerous, naturalisation of second country nationals, since such a policy would violate the principle of legitimate expectations. It is not impossible that making applications for indefinite leave to remain harder would also be held to be at odds with this general principle of European law.

Furthermore, the UK would be prevented from fighting instrumental naturalisation of its own nationals. It could not strip instrumental naturalisers of their British nationality and/or residence rights. It could be hard to prevent double residence for citizens with multiple nationalities. The UK might favour a return to the genuine link doctrine, developed by the Nottebohm-jurisprudence prevailing in international law, which considers citizenship to be 'a social fact of attachment' ${ }^{21}$ to claim that, if the person has his/her habitual residence or other key interests in the UK, the 'effective nationality' is the British membership, and not the nationality of the member state the person also is a member of. European law, however, prevents the UK from requiring such citizens to have a 'genuine link' with it. Finally, the UK would probably not be allowed to raise fees in any significant way for British nationals wishing to renounce nationality with the purpose of becoming naturalised in other parts of the Union.

In general terms, it would be detrimental to negotiations to harden the UK nationality laws and/or immigration laws. It should not be excluded that it would be favourable to negotiations to move in the opposite direction, for example, providing for automatic transformation of permanent residence into indefinite leave to remain, allowing second country nationals to naturalise without being subjected to citizenship tests or disproportionate fees. No such political will has been expressed.

\subsubsection{Consequences for Member States}

The policies listed above would fall within the remit of European law, allowing the European Court of Justice to scrutinise their legitimacy as long as the negotiations would last. The doctrinal limits in European law and their anticipated consequences for member states vis-à-vis UK nationals are also worthy of attention. Member states are hindered from a series of other actions that may tempt or that have already been suggested. In particular, there are limits to what member states can do to both assist and deter British citizens from continuing living in the Union and 
eventually naturalising there. Member states cannot 'punish' British citizens: Some countries having many nationals resident in the UK and that have been particularly targeted in the Brexit debate may not, for instance, render family reunification for British citizens harder, since it would violate the principle of legitimate expectations. Perhaps, it would also be advisable to let British citizens naturalise in Spain without enforcing the ban on dual nationality; or let them naturalise regardless of performance in integration tests in countries requiring these.

Academics have suggested naturalising Brits to save their rights (Kochenov 2016; Steinbeis 2016). Similar ideas have been voiced by senior politicians. Matteo Renzi hinted that British students might be offered naturalisation in Italy. German Vice-Chancellor Sigmar Gabriel said the remaining members should not 'pull up the drawbridge' for young Britons, and Germany should consider offering dual nationality to young British citizens. ${ }^{22}$ Such suggestions may be at odds with EU law. While individual naturalisation cases would fall within the competences of member states, it has become increasingly clear that were a member state to singlehandedly offer such en masse naturalisation it would challenge the principle of sincere cooperation. It is worth recalling that the Commission's DG Justice proceeded to infringement proceedings against Malta in relation to the Individual investor program initiated in 2013, which had been criticised by the European Parliament. It was the first time that a member state's nationality law was subjected to substantial amendment following an infringement proceeding. It has been pointed out both in literature (already in Kotalakidis 2000) and in court that the principle of sincere cooperation constitutes a limit to the exercise of state discretion, specifically in relation to what would be a mass naturalisation. If such naturalisation is to be an option, it requires the assent of the remaining 26 States. The Advocate General Poiares Maduro stated that provisions of primary Community legislation and the general principles of community law could restrict the legislative power of member states in the sphere of nationality: 'Thus, mention has been made (...) of the Community principle of sincere cooperation laid down in Article $10 \mathrm{EC}$, which could be affected if a member state were to carry out, without consulting the Commission or its partners, an unjustified mass naturalisation of nationals of non-member states. ${ }^{23}$

Finally, another possible doctrinal limit of EU law is the requirement to offer time to re-lapse. After Rottman, citizens need to have a chance, before their newly acquired member state nationality may be revoked, to 
apply for the re-acquisition of their old nationality. Commentators have ventured a reasonable timeframe would be 'a few years.' It is questionable if the Court would accept immediately effective deprivation. In the case of exit from the Union, this may be a doctrinal construct relevant to cover cases of second country nationals who naturalised in the exiting State but now wish to recover their original citizenship so as not to lose Union citizenship. Given the traditional tolerance of multiple citizenship in the $\mathrm{UK}$, nonetheless, this is unlikely to constitute an impediment in practice since naturalisers never were requested to renounce their prior status.

There are limits to what States can do, even within their domaine réservé that may prove to have repercussions on domestic legislation insofar as it is not overturned after exit. The limits stemming from European law are therefore significant, even though limited in time. To be sure, the European Court of Justice remains a powerful player throughout the negotiation phase. Perhaps later also were the European Court of Justice selected as conflict resolution mechanism in the withdrawal treaty. Yet it is far from clear that general principles of European law would be successfully invoked before UK courts. Some have rightly stressed that the introduction of Union citizenship places an important limit on the power of member state to deprive an individual of his or her nationality (Hall 1995, 1996, 2001). However it remains to be seen if limits to State discretion could offset domestic initiatives when at stake is the power of a former member state to deprive its own nationals of their Union citizenship.

\subsection{To Challenge Loss of Status}

For some: 'there is room for decoupling the concepts of nationality and Union citizenship: By maintaining Union citizenship in the case of loss of Member state nationality. (...) If the EU sees Union Citizenship as a fundamental status for the peoples of Europe, then the EU can determine that certain groups of people who lose their member state nationality will nonetheless remain Union citizens.' (Jessurun d'Oliveira 2011, p. 13)

Leaving aside the risk of introducing an unjustified distinction between cases of loss and cases of acquisition, it is a fact that there have been voices in favour of decoupling Union citizenship from member state nationality since the inception of the status. Normatively, it has long been argued that not only citizens of member states should be equipped with EU citizenship but also third country nationals who have established themselves in the Union (already in Føllesdal 1993). The political legitimacy of such a de-coupling 
would rely on the fact that, for the first time in the history of integration, Union citizens, who had automatically acquired their supranational citizenship with the Treaty of Maastricht, raised their political voice to state that they want to remain European citizens. European citizenship did not formally exist at the time of the 1975 UK referendum on EU membership, and citizens voting in the EU accession referendums in the context of the 2004 enlargements were not European citizens beforehand.

Leaving aside the political unlikelihood and the legal cumbersomeness of re-drafting primary EU legislation for a formal decoupling, little help for those advocating decoupling is to be found in international sources dealing with federal citizenship structures in the event of succession. ${ }^{24}$ Likewise pace some suggestions recently made ${ }^{25}$ - the genuine substance doctrine from Ruiz Zambrano, ${ }^{26}$ that overcomes the traditional requirement that Union citizenship be activated by border-crossing, would not allow decoupling: The doctrine, at odds with the reverse discrimination of static citizens (Tryfonidou 2008), has been much watered down. It is exceptional ${ }^{27}$ and the ratio decidend $i$ is to be interpreted strictly. ${ }^{28}$ It cannot serve as a basis for claims made by first country nationals, that is, nationals who have not made use of the freedom of movement, against the loss of status.

A more interesting candidate is the consequential reasoning in Rottman that specifically deals with loss of Union citizenship. In this case of great constitutional importance, the European Court of Justice concluded that 'a citizen of the Union who is faced with a decision withdrawing his [citizenship], and placing him $(\ldots)$ in a position capable of causing him to lose the status conferred by Article 17 EC [Article 20 TFEU] and the rights attaching thereto falls, by reason of its nature and its consequences, within the ambit of European Union law. 29 The reason why this case may carry precedential value is that the case focuses on loss of Union citizenship: The European Court of Justice decided that Janko Rottmann could, unlike Ms. Kaur, ${ }^{30}$ rely on his rights as a European citizen. Comparing the situation of Mr. Rottmann with that of Ms. Kaur, the denial of access to nationality would not constitute a problem, but the very fact that Rottmann once had the status of Union citizen, which he lost, was crucial in order to fall within the scope of European law. The Rottman doctrine is applicable not only to cases of deprivation when a fraud is discovered and the statelessness is the result, but also in other cases of deprivation, even if no statelessness is caused but the EU citizenship could be lost. ${ }^{31}$

The Rottman judgement points to a re-ordering of the relationship between member states' nationality and Union citizenship in favour of the 
latter. Gareth Davis, for one, speaks of abandonment of the hierarchy of the two concepts in favour of 'citizenship pluralism' (Davis 2011). Observers of the successive jurisprudence by the Court of Justice on Union citizenship were not surprised to discover the activism of Rottman: The readiness of the Court to dare take a further step in this 'holy' domain of the member states could easily have been foreseen. ${ }^{32}$ Since Micheletti, the Court has shown itself prepared to influence nationality laws in the case of a clear breach of Union law.

Before the activism of the court, ${ }^{33}$ however, doctrine is divided (Jessurun d'Oliveira et al. 2011). For some, the limits to a member state's ability to strip its nationals of access to European citizenship rights is essential for explaining the ratio of the institution of Union citizenship (its federal vocation) as well as the court's well established case-law; for others, it is a form of 'impérialism communautaire' (Ruzié 1993). While some claim the 'judicial avantguardism' is to be praised, for others, in this very case-law 'the court is persisting in its judicial error' (Jessurun d'Oliveira 2011, p. 9).

There is also an institutional twist to this doctrinal divide: While the caselaw of the European Court of Justice moves in the direction of making nationality matters a mixed competence, it simultaneously constitutes a dissenting voice when compared to the positions expressed by Member States, the Commission and the European Parliament that all seem to endorse the traditional reading of nationality matters being domaine réservé. In fact, the Commission has systematically taken the perspective of defending member state prerogative in nationality matters. Also the European Parliament has taken this view more often than not. The advocates of the opposed view, instead, insists on the decoupling of national and European citizenship: European citizenship is not merely 'derivative' (Maastricht) but then also 'complementary' (Treaty of Amsterdam) and, after Lisbon, EU citizenship is 'additional' (Geogiadou 2015, p. xix).

In this divided environment, it seems that the prima facie assurance that Brexit loss provision would not fall within the remit of Union law (since loss would only happen simultaneously to the UK's exit from the Union) is a bit shaken: 'By reason of its nature and its consequences' ${ }^{34}$ Brexit puts Union citizens of exclusively British nationality at risk of being stripped of their Union membership status in a way that might fall within the ambit of EU law.

If this is so, decisive are the possibilities to challenge the loss provision. Are there any venues for challenging the loss provision as such in which the consequentialist interpretation in Rottman might play a role? 
Challenging the loss of rights, where Rottman may be relevant, is possible, but loss of status is another matter. A possibility is the right of standing of a British second country national living in a member state who wishes to challenge the loss of status before a domestic court in the country of residence. One such case might involve for instance the British citizen who, on the basis of the status of Union citizenship, holds local political office of which (s)he will be discharged following Brexit. Dealing with such a case, a national court may refer to the European Court of Justice. Were the European Court of Justice to express itself in a preliminary ruling on the legitimacy of the loss of status as such, Rottman's ratio decidendi would apply. The Court might find the loss of Union citizenship to be inadmissible since it previously ruled that a 'national provision governing nationality [that] restricts the Union citizen without a legitimate interest and/or in a disproportionate manner' was such that the provision shall be put aside. Could it mean that Union citizenship ought to be recognised to the former Union citizenship? Ought (s)he be naturalised though a procedure of naturalisation by declaration (not by application, which would be open to all second country nationals anyway)? Could the local politician continue to stand in elections?

During the interregnum, that is, after invoking Article 50 but before exiting, would a British first country national be refused right of standing before a national (UK) court to challenge the loss provision? Albeit politically remote, would not the Court be free to activate a preliminary ruling procedure? If the European Court of Justice could be called into question, would it not be able to rely on its Rottman doctrine? In Rottman the crucial point was the loss of Union citizenship as such. Brexit would 'by reason of its nature and consequences' almost tautologically place many 'in a position capable of causing [them] to lose the status conferred by Art. 17 EC.' Were this line of reasoning followed, the European Court of Justice could open the constitutional dispute we referred to in Chapter 4: Union citizenship or Article 50 - aut aut? This certainly raises the question if the Court in Luxembourg is the authority to ask to fashion the constitutional arrangement in the European respublica composita (Beaud 2009, p. 222) or if this role ought not to be better allocated to democratically elected authorities.

Once closed, the interregnum, and this far-off window of legal opportunity in which the European Court of Justice could vindicate decoupling, there are no procedural venues through which former Union citizens could 
challenge their loss of status. International law provides that states are obliged to leave the possibility to citizens deprived of citizenship (no matter if it causes statelessness, and no matter if caused by administrative decision or by the workings of the law) the right to challenge the provision in court. But channels for challenging the loss of status following withdrawal from the Union are not explicitly provided for neither in European law, nor in domestic law. Were no venues open to challenge the loss of Union citizenship for British citizens, we would need to conclude that Article 50 introduces surreptitiously an unchallengeable new ground for loss of the status. It cannot be ruled out that, in keeping with international law, such an unchallengeable provision of loss might, after all, qualify as arbitrary.

\subsection{Enacting Union Citizenship}

Before the involuntary loss of status imposed on millions of British citizens on both sides of the border, it seems that the possibilities of challenging this provision are quite limited and unattractive.

The EU organs cannot by themselves push for decoupling. There is not much the Commission can do to hinder an exiting state from stripping those nationals who belong exclusively to the exiting state of the Union's status civitatis. There is a slight possibility that the European Court of Justice might push in this direction, on the basis of the Rottman doctrine. Doing so would pose serious risks: If impetus to decouple Union citizenship from nationality derives from a decision by the European Court of Justice it can be attacked on democratic grounds and be found at odds with the current constitutional arrangement of the EU. The Court of Justice could exploit this window of opportunity, but only at the cost of showing itself uninterested in obeying to democratic standards and perhaps also disposed to perturb the constitutional arrangement.

The EU member states are in a better position to further decoupling in order to save the status for (at least some) British nationals. Some scholars have suggested they use this position to create 'a form of Union citizenship unmediated by any prior national citizenship' (Morgan 2016). Of course, there is the impervious road of re-drafting the Treatises but, given its political improbability and legal impracticality, I shall put this option aside. Nonetheless, the Council may help to coordinate member states wishing to ease naturalisation for locally residing British citizens, automatically transform the status of permanent residents into third country national long-term residents, or in other ways seek to either maintain the 
status of Union citizen for post-European Brits or to freeze rights. Whereas a member state is not free to engage in mass naturalisation on its own initiative (lest it violates the principle of sincere cooperation), coordinated member states are not liable to objections about undemocratic or unconstitutional behaviour to the same extent as a court.

Last but not least, there is another way to save the status that has hitherto been overlooked: Union citizens themselves might push for decoupling. This can be done in two different ways.

The first way consists in activating a citizens' initiative (Art. $11 \$ 4$ TEU). If a million EU citizens, coming from at least seven member states, sign an initiative and the Commission decides to propose legislation as a result of it, the status of Union citizenship may well prove to be 'destined to become the fundamental status' of nationals of (former) member states as well. It is politically remote that, first, Union citizens show much solidarity with remainers; and second, that the Commission, who, in its role of guardian of the Treatises, generally endorses the traditional reading of nationality matters being domaine réservé (see above 6.3.), would favour decoupling. As a matter of law, it remains possible for Union citizens to help British citizens who have been stripped of the status they once shared. There are constitutionally foreseen venues, so unsettling of the arrangement would not be necessary. The democratic quality of such an initiative would not be challenged as it emerges bottom-up: It is the very role of citizens within a polity to be mindful about the primordial political right of defining the demos.

Moreover, the citizenship initiative introduced by the Treaty of Lisbon is itself a supranational political instrument. The citizens' initiative introduced by the Treaty of Lisbon was framed specifically for giving voice to cross-national political concerns on the basis of a political conception of EU citizenship: The Regulation of the EU Parliament and the Council on the citizens' initiative from 2010 emblematically fixes the threshold at ' $0.2 \%$ of the population.' Also, there would have been no point in setting different thresholds for different countries if the petition names were to stand merely for national interests rather than a cross-national opinion.

It is one of the elements that allows to make the claim that Union citizenship does not merely consist in mutually recognised privileges, but also in supranational political rights. Using it to save the supranational political rights of citizens that risk losing these - because of decisions possibly made by a member state government following a non-binding referendum in which the most affected were effectively 
disenfranchised ${ }^{35}$ - strengthens the claim that an initiative on decoupling with the purpose of saving the status as Union citizens for British resident in the Union ought to be taken seriously even by a Commission otherwise reluctant to move in this direction. Were the Commission to take up the challenge, it would find that the Rottman doctrine of the European Court of Justice would go a long way in doing the job of explaining why loss of Union citizenship cannot be imposed unilaterally by one's (ex member) state of nationality.

There are solutions that would enable the Union citizenry to enact its citizenship, as Engin Isin has called it (Isin and Saward 2015), by becoming politically active and willing to contest arbitrary exercises of power.

Another way to enact citizenship is the second way for Union citizens to push for decoupling. The two ways are not alternative and can be pursued in parallel. Given the passivity of the non-British public before Brexit, the disenfranchised British citizens, with no other member state nationality to rely on, that are being deprived of the status of Union citizens, in a way that will also result, in a number of member states, in losing their local political citizenship, may petition the European Parliament to ask for a decoupling that will allow them to keep their status. The Parliament, even though sometimes reticent towards to the activism of the European Court of Justice in nationality and citizenship matters, is, contrarily to the Commission, the institution potentially most favourable to decoupling: It has on several occasions viewed its own mandate as representing the population of the Union and not merely the sum of nationals of member states. ${ }^{36}$ Petitioning Parliament does not amount to political initiative, but it could lead to a declaration by the Parliament inviting the Council and the Commission to provide for the loss of status. Since it would only concern former Union citizens and not all residents, there are chances a plea might be taken seriously.

This way to 'save' the citizenship of deprived British nationals remains open after Brexit occurs. All residents may petition the Parliament and, as we have seen, there are reasons for believing that British citizens currently resident in the Union will see their residence rights frozen.

\section{Notes}

1. European Parliament, OJ C 77/53, 19 March 1984.

2. A terminological remark is needed: There are many expressions relating to loss of status civitatis: loss, quasi-loss (or ex tunc declaration of invalidity), deprivation, lapse, withdrawal, renunciation. Deprivation or withdrawal is 
usually an administrative measure by the competent authorities whilst lapse or ex lege loss happens automatically by operation of the law. Renunciation is voluntary. See Glossary Eudo-citizenship, available at http://eudo-citizen ship.eu/databases/citizenship-glossary (last accessed 30 October 2016). See Weis 1979; De Groot 2015, at 10.

3 . The UK supreme court refused the permission to appeal on the grounds of purely domestic law, leaving all EU citizens of UK nationality residing in other member states disenfranchised in the referendum: UKSC 2016/0105. See e.g. Ziegler 2016.

4. See Chapter 2. The ability to disconnect member state nationality from EU citizenship, although confirmed in Kaur, is much more difficult for the member states to use after Rottmann.

5. My italics.

6. BVerfG, 2 BvE 2/08, 30/06/09, $\$ 350$.

7. See Chapter 2. This choice give rise to concerns both for the political legitimacy of the construct and for legal foreseeability in certain hard cases: Mindus 2008; Mindus and Goldoni 2012. For a comparative reading with federal settings, see Schönberger 2005.

8. See the research results of the ILEC project: Carrera Nunez, De Groot 2015; De Groot and Vonk 2016.

9. The UNDHR is here reminiscent of the Decree of Adolf Hitler of 25 November 1941 that determined loss ex lege of status for Jewish citizens of Germany.

10. For a general overview, UN Human Rights Council (12009), Human Rights and Arbitrary Deprivation of Nationality: Report of the SecretaryGeneral, 14 December, A/HRC/13/34.

11. These principles include that a loss of citizenship requires (1) firm legal basis; (2) may not be enacted retroactively; (3) in case of the introduction of a new ground of loss, a reasonable transitory provision has to be made to avoid an individual losing his nationality due to an act that had already started before the introduction of the new ground for loss; (4) a legal provision regarding the acquisition of nationality may not be repealed with retroactivity; (5) the principle tempus regit factum applies; (6) loss provisions must be easily accessible and predicable; (7) the ground given for deprivation must be proportional; (8) provisions may not be discriminatory; (9) it must be possible to challenge the application of loss provisions in court. Full list and analysis in De Groot 2015, at 9-39.

12. See Chapter 2.

13. Mario Vicente Micheletti and others v Delegación del Gobierno en Cantabria, Case C-369/90 \$ 10.

14. Case C-315/08, Janko Rottman v. Freistaat Bayern, $\$ 51$.

15. Among those who have insisted on this, there is the Institute for Public Policy Research that maintained in a recent report that a fundamental 
reform of the UK citizenship policy is required after Brexit. See Murray 2016.

16. One reading of this term may be those having exercised 'treaty rights' or are in process of doing so.

17. Notice, for example, that $2 / 3$ flopped the Danish citizenship test recently. The test includes questions such as which Danish restaurant has three Michelin stars. It is not Noma.

18. See note 21.

19. Belgium, Cyprus, Denmark, Finland, France, Ireland, Malta, Netherlands, Spain, Sweden. The details of these rules vary considerably in procedure (lapse vs. withdrawl), personal scope (naturalised, foreign-born citizens or all), statelessness (only for dual citizens or not), age, and connected sanctions.

20. Given the large number of British nationals currently living in Spain, it is worth recalling that Spain does enforce such a ban.

21. Nottebohm 6 April 1955, Liechtenstein v. Guatemala, CIJ Recueil, at $23 \mathrm{ff}$. Glazer 1955; Bastide 1956; Maury 1958; Weis 1979, esp. 176-181 and 318-321. A national of a member state who is also a national of a nonmember state is a EU citizen regardless of social ties or place of residence: since the ruling in Mario Vicente Micheletti v Delegación del Gobierno en Cantabria (Case C-369/90), the European Court of Justice favours a formalist reading that distances itself from the doctrine of 'genuine link.' See Chapter 2.

22. http://www.spiegel.de/politik/deutschland/brexit-sigmar-gabriel-for dert-doppelte-staatsbuergerschaft-fuer-junge-briten-a-1101010.html (last accessed 30 October 2016).

23. Opinion of AG Poiares Maduro in Case C-135/08, Rottman [2010] ECR I-01449.

24. In 2006 the Council of Europe adopted a new specific Convention of the Avoidance of Statelessness in Relation to State Succession that establishes that the successor state should grant nationality to certain nationals of the predecessor State if they would otherwise become stateless. This specific group includes those who are habitually resident in the successor state, those with a legal bond through federal citizenship, those born there or having their last habitual residence there before leaving the predecessor state. It is ratified only by Austria, Hungary and the Netherland.

25. It has been suggested that the Ruiz Zambrano doctrine on 'genuine substance' would be relevant to allow decoupling: it would: replicate the emancipatory move of Van Gend en Loos - to liberate individuals from the preferences of their states. De-coupling would signify a constitutional recognition that rights acquired as European citizens really are 'fundamental': integral to individual personhood and therefore inscribed into the deep structure of an autonomous EU legal order (Dawson and Augenstein 2016). 
26. Case C-34/09, Ruiz Zambrano EU:C:2011:124. The Court supplemented the protection of the status of Union citizenship with the requirement that the substance of rights attached to the status be enjoyed. The ECJ resorted to the 'substance' of European citizenship to ground the entitlement of a third country national to reside and work in Belgium as the father care-taker of two children who had been born nationals of Belgium in order to avoid statelessness that would have followed from being born by Colombian nationals who did not reside in Colombia (Colombia being a country applying ius soli quite strictly): 'Article 20 TFEU precludes national measures which have the effect of depriving citizens of the Union of the genuine enjoyment of the substance of the rights conferred by virtue of their status as citizens of the Union. A refusal to grant a right of residence to a third country national with dependent minor children in the Member State where those children are nationals and reside, [.. ] has such an effect.'

27. See Case C-256/2011, Dereci EU:C:2011:734; Case C-434/09, Shirley McCarthy EU:C:2011:277.

28. It does not cover lesser interferences such as with the mere desire to keep a family together in a given member state. See Joint Cases 356/11 and 357/ 11, O, S EU:C:2012:776, $\$$ 52; Case C-87/12, Ymeraga EU:C:2013:291, $\$$ 38. Also see Case C-86/12, Alokpa EU:C:2013:645.

29. Case C-135/08 Janko Rottmann v Freistaat Bayern [2010] ECR nyp, $\$ 42$.

30. In the case of Kaur (16 Case C-192/99 The Queen v Secretary of State for the Home Department, ex parte: Manjit Kaur [2001] ECR I-01237), the British nationality rules were examined by the European Court of Justice. In that case a third country national who was recognised by the UK as citizen of the UK and Colonies but did not fall within the personal scope of citizens entitled to right to abode, could not rely on her Union citizenship. The European Court of Justice held, in that case, that the declaration on nationality of the UK 'did not have the effect of depriving any person who did not satisfy the definition of a national of the UK of rights to which that person might be entitled under Community law. The consequence was rather that such rights never arose in the first place for such a person.' Kaur is a case of quasi loss, Rottman a case of loss.

31. See ILEC Guidelines IV.5.c. and V.a.; De Groot 2015, at 35.

32. On Rottman, and for extensive comments on why it was not a judgment 'out of the blue' but rather consistent with previous activism of the European Court of Justice: see http://eudo-citizenship.eu/commen taries /254-has-the-european-court-of-justice-challenged-member-statesovereignty-in-nationality-law? start=1 (last accessed 30 October 2016).

33. The case-law of the European Court of Justice generally has been pointing towards avantguardism of pushing EU citizenship beyond the merely economically motivated concept. See cases such as Baubast (C-413/99), 
Martinez-Sala (C-85/96), Grzelczyk (C-184/99), Garcia Avello (C-148/ $02)$ and Bidar (C-209/03).

34. De Groot calls this doctrine 'an even more sensational construct' that the claim made by the Advocate General Maduro that since Rottman was born Austrian and made use of his EU citizenship and his freedom of movement when moving to Germany, the case ought not to be considered a 'purely internal one' (De Groot 2010).

35. See note 3 .

36. For example, during the 2007 intergovernmental conference, Italy did not approve the new composition of the European Parliament. On this incident, see Manzella 2008. The proposal voted by the European Parliament had used a formula based on resident population rather than 'citizenship' (i.e. nationality). It would have left Italy with 72 seats compared to 73 for the UK, 74 for France (that had historically had the same weight as Italy). This dispute led to Declaration 4 attributing the extra seat to Italy and to Declaration 57 on the definition of citizenship.

\section{REFERENCES}

Bastide, S. (1956) 'L'affaire Nottebohm devant la Cour Internationale de Justice', 45 Revue critique de droit international privé 607-633.

Beaud, O. (2009) Théorie de la fédération, Paris: Puf.

Carrera Nuñez, S., De Groot, G.-R. (eds.) (2015) European Citizenship at the Crossroads. The Role of the European Union on Loss and Acquisition of Nationality, Oisterwijk: Wolf.

Davis, G. (2011) 'The Entirely Conventional Supremacy of Union Citizenship and Rights', Commentary in 'Has the European Court of Justice Challenged Member State Sovereignty in Nationality Law?' Forum Debates EUDO, available at http://eudo-citizenship.eu/commentaries/citizenship-forum/citizen ship-forum-cat/254-has-the-european-court-of-justice-challenged-memberstate-sovereignty-in-nationality-law? showall=\&start=1 (last accessed $\quad 30$ October 2016).

Dawson, M., Augenstein, D. (2016) 'After Brexit: Time for a Further Decoupling of European and National Citizenship?' VerfBlog, 14 July 2016, available at http://verfassungsblog.de/brexit-decoupling-european-national-citizenship/ (last accessed 30 October 2016).

De Groot, G.R. (2004) 'Towards a European Nationality Law', Electronic Journal of Comparative Law 8, available at http://www.ejcl.org/83/art83-4.html (last accessed 30 October 2016).

De Groot, G.R. (2010) 'Invloed van het Unierecht op het nationaliteitsrecht van de Lidstaten: Overwegingen over de Janko Rottman-beslissing van het Europees Hof van Justitie', 5/6 Asiel \& Migratierecht, 293-300. 
De Groot, G.-R. (2015) 'Survey on the Rules on Loss of Nationality in International Treatises and Case Law', in S. Carrera Nuñez, G.-R. De Groot (eds.) European Citizenship at the Crossroads. The Role of the European Union on Loss and Acquisition of Nationality, Oisterwijk: Wolf Legal Publishers.

De Groot, G.-R., Vonk, O. (2016) International Standards on Nationality Law: Text, Cases and Materials, Oisterwijk: Wolf Legal Publishers.

De Mars, S., Murray, C., O'Donoghue, A., Warwick, B. (2016) 'Brexit-ing Northern Ireland: The Challenges Ahead', DeliBlog, Blog entry from 11 July 2016, available at https://delilawblog.wordpress.com/2016/07/11/sylviade-mars-colin-murray-aoife-odonoghue-ben-warwick-brexit-ing-northern-ire land-the-challenges-ahead/ (last accessed 30 October 2016).

Dzankic, J. (2016) 'Brexit and Citizenship', Report EUDO blog entry 27 June 2016, available at http://eudo-citizenship.eu/news/citizenship-news/1636brexit-and-citizenship (last accessed 30 October 2016).

Evans, A.C. (1991) 'Nationality Law and European Integration', 16 European Law Review 190.

Føllesdal, A. (1993) 'Third Country Nationals as Euro-Citizens - The Case Defended', in D. Smith, S. Wright (eds.) Whose Europe? The Turn Towards Democracy, Blackwell: London, 104-122.

Fransman, L. (2011) Fransman's British Nationality Law, 3rd ed., West Sussex: Bloomsbury Professional.

Geogiadou, Z. (2015) 'Foreword', in S. Carrera Nuñez, G.-R. De Groot (eds.) European Citizenship at the Crossroads. The Role of the European Union on Loss and Acquisition of Citizenship (ILEC), Oisterwijk: Wolf Legal Publishers.

Glazer, J.H. (1955) 'Affaire Nottebohm (Lichtenstein v. Guatemala), A Critique', 44 Georgetown Law Journal 1955/56 313-325.

Glossary Eudo-Citizenship available at http://eudo-citizenship.eu/databases/citi zenship-glossary (last accessed 30 October 2016).

Hall, S. (1995) Nationality, Migration Rights and Citizenship of the Union, Leiden: Martinus Nijhoff.

Hall, S. (1996) 'Loss of Union Citizenship in Breach of Fundamental Rights', 21 European Law Review 488.

Hall, S. (2001) 'Determining the Scope ratione personae of European Citizenship: Customary International Law Prevails for Now', 28(3) Legal Issues of Economic Integration, 355-360.

Howarth, D.J. (1994) 'The Compromise on Denmark and the Treaty on the European Union: A Legal and Political Analysis', 31 Common Market Law Review 4, 765-805.

Isin, E., Saward, M. (2015) Enacting European Citizenship, Cambridge: CUP.

Jessurun d'Oliveira, H.U. (2011) 'Court of Justice of the European Union: Decision of 2 March 2010, Case C-315/08, Janko Rottman v. Freistaat 
Bayern Case Note 1 Decoupling Nationality and Union Citizenship?', 7 European Constitutional Law Review 1, $138 \mathrm{ff}$.

Jessurun d'Oliveira, H.U., De Groot, G.-R., Seling, A. (2011) 'Court of Justice of the European Union: Decision of 2 March 2010, Case C-315/08, Janko Rottman v. Freistaat Bayern Case Note 1 Decoupling Nationality and Union Citizenship? Case Note 2 The Consequences of the Rottmann Judgment on Member State Autonomy - The European Court of Justice's Avant-Gardism in Nationality Matters', 7 European Constitutional Law Review 1, 138-160.

Kochenov, D. (2016) EU Citizenship and Withdrawals from the Union: How Inevitable is the Radical Downgrading of Rights?, LEQS Paper No. 111/ 2016, available at http://www.lse.ac.uk/europeanInstitute/LEQS\% 20Discussion\%20Paper\%20Series/LEQSPaper111.pdf (last accessed 30 October 2016).

Kotalakidis, N. (2000) Von der nationalen Staatsangehörigkeit zur Unionsbürgerschaft. Die Person und das Gemeinwesen, Baden: Nomos.

Manzella, A. (2008) 'Un trattato necessitato', in F. Bassanini, G. Tiberi (eds.) Le nuove istituzioni europee. Commento al Trattato di Lisbona, Bologna: Il Mulino. $438 \mathrm{ff}$.

Marescaux, M.H. (1984) 'Nationalité et statut personnel dans les instruments internationaux des Nations Unies', in M. Verwilghen (ed.) Nationalité et statut personnel: Leur interaction dans les traités internationaux et dans les législations nationales, Bruxelles: Bruylant.

Maury, J. (1958) 'L'arrêt Nottebohm et la condition de nationalité effective', 23 Zeitschrift für ausländisches und internationales Privatrecht 515-534.

Mindus, P. (2008) 'Europeanisation of Citizenship within the EU: Perspectives and Ambiguities, Jean Monnet Series of Working Paper', available at https:// iris.unito.it/retrieve/handle/2318/82213/11168/MINDUS\%20JM\%20WP \%20in\%20rete.pdf (last accessed 30 October 2016).

Mindus, P., Goldoni, M. (2012) 'Between Democracy and Nationality: Citizenship Policies in the Lisbon Ruling', 18 European Public Law 2, 351-371.

Morgan, G. (2016) 'Union Citizenship for UK Citizens', EUDO Forum Debates Freedom of Movement Under Attack: Is it Worth Defending as the Core of EU Citizenship?, available at http://eudo-citizenship.eu/commentaries/citizen ship-forum/citizenship-forum-cat/1586-freedom-of-movement-underattack-is-it-worth-defending-as-the-core-of-eu-citizenship? showall=\&start=1 1 (last accessed 8 November 2016).

Murray, C. (2016) 'Becoming One of Us: Reforming the UK's Citizenship System for a Competitive, Post-Brexit World, Report for the Institute for Public Policy Research', available at http://www.ippr.org/publications/becoming-one-of-us (last accessed 30 October 2016).

Ruzié, D. (1993) 'Nationalité, effectivité et droit communautaire', 97 Revue générale de droit international public 107-120. 
Schönberger, C. (2005) Unionsbürger: Europas föderales Bürgerrecht in vergleichender Sicht, Tübingen: Mohr.

Steinbeis, M. (2016) Nach dem Brexit-Referendum: ein Fast Track zur deutschen Staatsbürgerschaft für bedrohte Unionsbürger!', VerfBlog, 24 June 2016, available at http://verfassungsblog.de/brexit-fast-track-staatsbuergerschaft-union sbuerger/ (last accessed 30 October 2016).

Tryfonidou, A. (2008) 'Reverse Discrimination in Purely Internal Situations: An Incongruity in a Citizens' Europe', 35 Legal Issues of Economic Integration 43.

Weis, P. (1979) Nationality and Statelessness in International Law, 2nd ed., London: Stevens \& Sons.

Ziegler, R. (2016) 'The Referendum of the UK's EU Membership: No Legal Salve for its Disenfranchised Non-resident Citizens', VerfBlog, 21 June 2016 available at http://verfassungsblog.de/the-referendum-of-the-uks-eu-member ship-no-legal-salve-for-its-disenfranchised-non-resident-citizens/ (last accessed 30 October 2016).

Open Access This chapter is licensed under the terms of the Creative Commons Attribution 4.0 International License (http://creativecommons.org/licenses/ by $/ 4.0 /$ ), which permits use, sharing, adaptation, distribution and reproduction in any medium or format, as long as you give appropriate credit to the original author(s) and the source, provide a link to the Creative Commons license and indicate if changes were made.

The images or other third party material in this chapter are included in the book's Creative Commons license, unless indicated otherwise in a credit line to the material. If material is not included in the book's Creative Commons license and your intended use is not permitted by statutory regulation or exceeds the permitted use, you will need to obtain permission directly from the copyright holder.

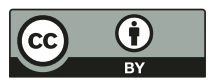

